\title{
Effect of Vacuum Annealing Temperature on the Binary System Ni/Si(100)
}

\author{
R. Mezouar ${ }^{1, *}$, A. Merabet ${ }^{2}$, A. Bahloul ${ }^{3, \dagger}$ \\ ${ }^{1}$ Laboratoire Matériaux et Systèmes Electroniques, Université Mohamed El Bachir El Ibrahimi de Bordj Bou Arre- \\ ridj, Bordj Bou Arreridj 34000, Algérie \\ ${ }^{2}$ Institue d'Optique et Mécanique de Précision, Université Farhat Abbas Setif, 19000, Algérie \\ ${ }^{3}$ Département de Génie de l'Environnement, Université Mohamed El Bachir El Ibrahimi de Bordj \\ Bou Arreridj, Bordj Bou Arréridj 34000, Algérie
}

(Received 25 July 2020; revised manuscript received 15 December 2020; published online 25 December 2020)

\begin{abstract}
Metal silicide films are widely applied in microelectronic industry, they have been used as rectifier and ohmic contacts. Most of metals react with silicon to form silicide, the deposition of a thin metal layer is obtained by different techniques. The common methods are vacuum evaporation with filament or e-gun, sputtering, and chemical vapor deposition. The vacuum deposition of a thin layer of metal on a silicon substrate is one of the most widely used. The metal silicide film is grown on a silicon substrate and then annealed at different thermal budgets. In this work, to prepare a silicide film, we have used as a technique vacuum evaporation PVD (physical vapor deposition) by using a nickel (Ni) filament with high purity. On a substrate of naturally oxidized $\mathrm{Si}(100)$ and after HF surface preparation, two layers of nickel are deposited, namely of $56 \mathrm{~nm}$ and $35 \mathrm{~nm}$. These different samples $(\mathrm{Ni}(56 \mathrm{~nm}) / \mathrm{Si}(100)$ and $\mathrm{Ni}(35 \mathrm{~nm}) / \mathrm{Si}(100))$ were then vacuum annealed at different thermal budgets and at temperatures equal to $350,500,650$ and $750{ }^{\circ} \mathrm{C}$ for a time equal to $30 \mathrm{~min}$. The characterization of the obtained layers was made by the following techniques: $\mathrm{X}$-ray diffraction (XRD) for studying the structure of the films (phase identification), the four-point probe technique for measuring the sheet resistance of the phase(s), and the surface roughness study was carried out using atomic force microscopy (AFM). The growth of $\mathrm{Ni}$ on naturally oxidized $\mathrm{Si}(100)$ substrates has been studied by different techniques which confirmed that the vacuum annealing temperature has a very important effect, NiSi monosilicide phase appears from $650^{\circ} \mathrm{C}$. The morphology analysis of the interface revealed the presence of different phases $\mathrm{NiSi}, \mathrm{NiO}$ and $\mathrm{Ni}_{2} \mathrm{O}_{3}$ which is confirmed by structural analysis. Also, good coherence was observed between XRD results with those of the sheet resistance and the RMS surface roughness measurements.
\end{abstract}

Keywords: Silicide, Evaporation by Joule effect, RCA, XRD, AFM, Sheet resistance, RMS.

DOI: 10.21272/jnep.12(6).06005

PACS numbers: 61.05.C -, 68.37.Ps

\section{INTRODUCTION}

There is a vast literature on the formation of nickel silicides ( $\left.\mathrm{Ni}_{2} \mathrm{Si}, \mathrm{NiSi}, \mathrm{NiSi}_{2}, \ldots\right)$. Traditionally, compounds are formed from a deposit of nickel produced on a previously cleaned silicon substrate. Then, the silicide is formed by vacuum annealing. In most studies, relatively thick silicide films are formed with an initial thickness of a deposited metal from 50 to $100 \mathrm{~nm}$. For these thickness ranges, it has been shown that the phase formation sequence of nickel silicide for an increasing thermal budget is as follows $[1,2]$ :

$$
\mathrm{Ni} \stackrel{250^{\circ} \mathrm{C}}{\longrightarrow} \mathrm{Ni}_{2} \mathrm{Si} \stackrel{350^{\circ} \mathrm{C}}{\longrightarrow} \mathrm{NiSi} \stackrel{900^{\circ} \mathrm{C}}{\longrightarrow} \mathrm{NiSi}_{2} .
$$

Nickel silicide (NiSi) is a material which finds application in both Complementary Metal Oxide Semiconductor (CMOS) devices [3, 4].

Nickel silicide thin films are used in ohmic contacts in the CMOS industry due to their low resistivity $[5,6]$, low silicon consumption and low processing temperature compared to titanium silicide and cobalt silicide $[7,8]$. For instance, Ni-rich silicides, like $\mathrm{Ni}_{3} \mathrm{Si}, \mathrm{Ni}_{2} \mathrm{Si}$ and $\mathrm{Ni}_{31} \mathrm{Si}_{12}$, can be used for $p$-MOS gates due to their higher work function, while $\mathrm{NiSi}, \mathrm{NiSi}_{2}$ and $\mathrm{Ni}_{3} \mathrm{Si}_{2}$ are attractive for $n$-MOS applications [9].

\footnotetext{
*mezouar_r@yahoo.fr

†ahmbahloul@yahoo.fr
}

In the experiment, during the formation of nickel silicide films after annealing in the ambient atmosphere a nickel oxide ( $\mathrm{NiO}$ ) phase could be formed. $\mathrm{NiO}$ is an interesting material because of its chemical and thermal stability, it has a set of physical properties (optical, magnetic etc.) capable of using it in numerous applications in the field of electronics and optoelectronics [10]. $\mathrm{NiO}$ is an anti-ferromagnetic and a $p$-type conductivity semiconductor with a large optical gap between 3.6 and $4.0 \mathrm{eV}$ [11].

Among the applications of $\mathrm{NiO}$ thin films, we cite that this material is used as an anode in oxygen fuel cells, as an active material in chemical gas sensors. In addition, the application of this compound is found in other optoelectronic devices (elements for displaying information, variable reflection mirrors etc.) [12].

In this work, on the substrate of $p$-type monocrystalline silicon (100), two layers of nickel are deposited, namely (56 nm and $35 \mathrm{~nm}$ ), by thermal evaporation by Joule effect. These different samples (Ni(56 nm)/Si(100) and $\mathrm{Ni}(35 \mathrm{~nm}) / \mathrm{Si}(100))$ were then annealed at different thermal budgets from 350 until $750{ }^{\circ} \mathrm{C}$ for a time equal to $30 \mathrm{~min}$. All prepared samples are characterized by different techniques (XRD, Four-point probe, AFM).

The resulting structural properties of the silicide layer are promising to improve the structural and electrical stability of NiSi. 


\section{EXPERIMENTAL PROCEDURE}

The vacuum deposition of pure nickel was carried out on a naturally oxidized $\mathrm{Si}(100)$ substrate. The $\mathrm{Si}$ monocrystalline silicon wafer was $p$-type having a resistivity between 12 and 20 S.cm and a thickness of $400 \mu \mathrm{m}$. The silicone substrates were treated and cleaned by HF solution. Then, two films of nickel were deposited with thicknesses equal to $56 \mathrm{~nm}$ and $35 \mathrm{~nm}$ by PVD (physical vapor deposition) and thermal evaporation by Joule effect. In order to study the stability of the interface of $\mathrm{Ni}(56 \mathrm{~nm}) / \mathrm{Si}$ and $\mathrm{Ni}(35 \mathrm{~nm}) / \mathrm{Si}$ systems as a function of temperature, we subjected our samples to the conventional thermal vacuum annealing RCA at temperatures of $350,500,650$ and $750{ }^{\circ} \mathrm{C}$ for $30 \mathrm{~min}$. The characterization of the obtained films was made by the following techniques: X-ray diffraction (XRD), electrical resistivity measurement by the four-point probe method, atomic force microscopy (AFM).

\section{DISCUSSION OF RESULTS}

\subsection{Structural Characterization: XRD}

In the grazing incidence analysis, the sample receives an incident beam at a fixed angle of $0.5^{\circ}$, and the detector rotates over a range of 10 to $100^{\circ}$ in the $2 \theta$ scale. It also makes it possible to increase the diffraction volume and therefore to measure very thin films up to around $10 \mathrm{~nm}$ thick [13]. In the diffractometer, Xrays were produced from a CuKa radiation source having a wavelength equal to $1.540593 \AA$. We have based on JCPDS file $\mathrm{No}^{\circ} 47-1049$ to identify the different diffraction peaks measured from our thin films. The scan angle varied from $2 \theta=25^{\circ}$ to $80^{\circ}$ with a step size of 0.01 and at a rate of $1.57 \mathrm{~min}$.

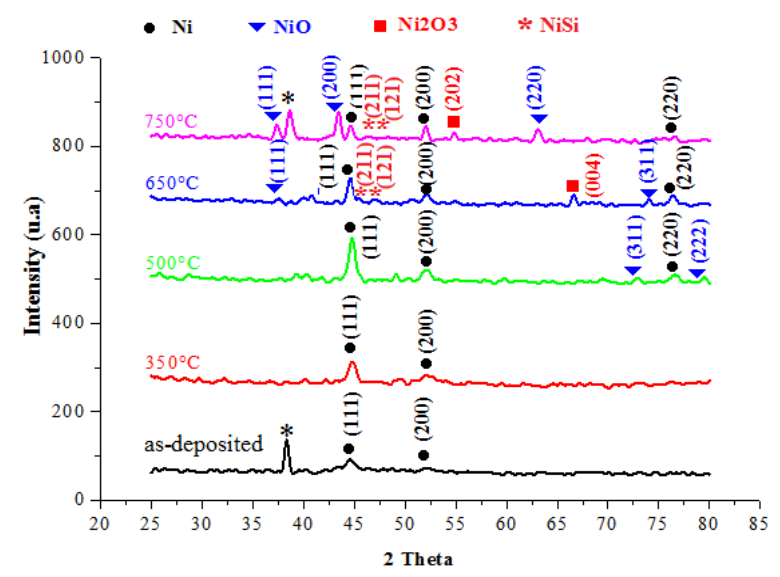

Fig. 1 - XRD spectra of the $\mathrm{Ni}(35 \mathrm{~nm}) / \mathrm{Si}$ system for annealing temperatures from $350{ }^{\circ} \mathrm{C}$ to $750{ }^{\circ} \mathrm{C}$ for $30 \mathrm{~min}$

Fig. 1 and Fig. 2 show XRD patterns of Ni/Si samples annealed at different temperatures $(350,500,650$ and $750{ }^{\circ} \mathrm{C}$ ) for a time of $30 \mathrm{~min}$, the samples have different thickness of 35 and $56 \mathrm{~nm}$.

The XRD data clearly show distinct peaks at $2 \theta$ of $44.82,51.95$ and 76.47. The peaks have been identified from (JCPDS Card No 04-0850) as peaks of Ni particles with various diffraction planes [111], [200] and [220].

The XRD pattern revealed the formation of $\mathrm{NiO}$ phase at 37.47, 44.58, 63.09, 74.59 and 79.47 which are

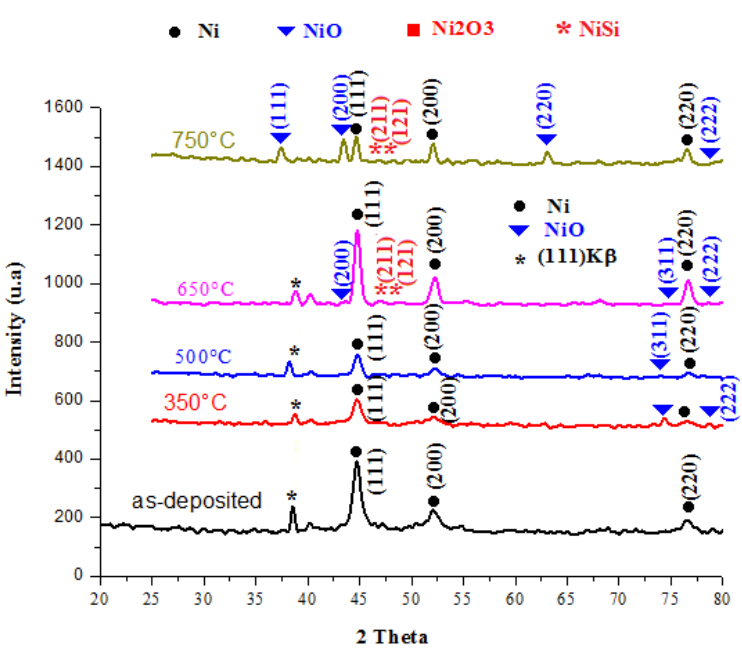

Fig. 2 - XRD spectra of the $\mathrm{Ni}(56 \mathrm{~nm}) / \mathrm{Si}$ system for annealing temperatures from $350{ }^{\circ} \mathrm{C}$ to $750{ }^{\circ} \mathrm{C}$ for $30 \mathrm{~min}$

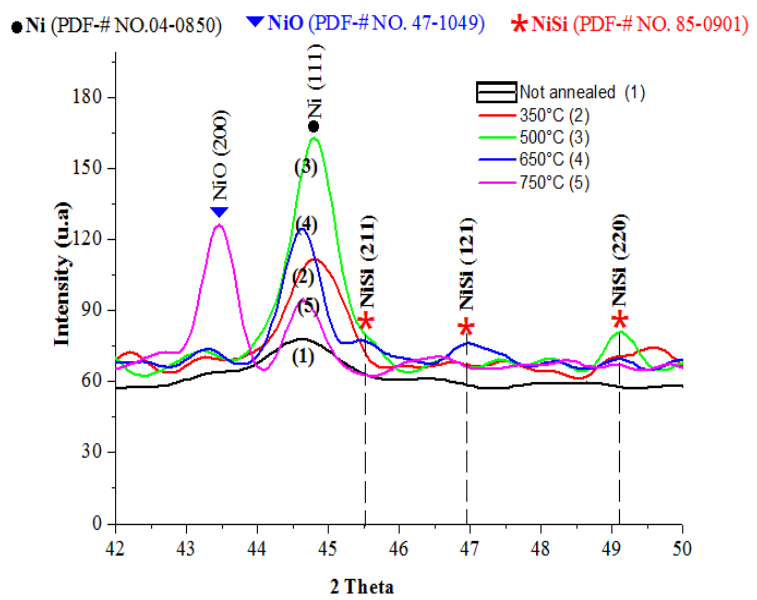

Fig. 3 - XRD spectra $\left(42^{\circ}<2 \theta<50^{\circ}\right)$ of the $\mathrm{Ni}(35 \mathrm{~nm}) / \mathrm{Si}$ film for annealing temperatures from $350{ }^{\circ} \mathrm{C}$ to $750{ }^{\circ} \mathrm{C}$ for $30 \mathrm{~min}$

attributed to diffraction planes [111], [200], [220], [311] and [222](JCPDS Card No 47-1049).

The other peaks, observed at angles $2 \theta$ of 31.32 , 54.95 and 66.59 , have been identified as $\mathrm{Ni}_{2} \mathrm{O}_{3}$ corresponding to [002], [202] and [004] planes, respectively.

A peak at $2 \theta$ of $38.33(*)$ is frequently observed which corresponds to the cello tape used for holding the samples. The obtained results confirm the presence of $\mathrm{Ni}$ on $\mathrm{Si}$, but annealing of the samples over $350{ }^{\circ} \mathrm{C}$ leads to a fairly homogeneous formation of a $\mathrm{NiO}$ film containing a small amount of $\mathrm{Ni}_{2} \mathrm{O}_{3}$ as impurities.

The annealed samples with $56 \mathrm{~nm}$ of thickness do not show the presence of $\mathrm{Ni}_{2} \mathrm{O}_{3}$ impurities.

Nickel silicide thin films were also analyzed using glancing angle XRD. The peaks obtained in the diffractograms (Fig. 3 and Fig. 4) were compared with the International Committee for Diffraction Data powder diffraction file (JCPDS Card No 85-0901) for indexing. The diffractograms show the XRD peaks obtained while the sample was heated from 350 to $750{ }^{\circ} \mathrm{C}$.

Nickel and silicide peaks are concentrated in the $2 \theta$ range of $42-50^{\circ}$; the peak at $44.82^{\circ}$ is the nickel peak due to thermal expansion, peak shift. When the sample reaches a temperature over $350{ }^{\circ} \mathrm{C}$ many small peaks appear at $45.51^{\circ}, 46.94^{\circ}$ and $49.1^{\circ}$ which correspond to 
NiSi(211), NiSi(121) and NiSi(220) monosilicides, respectively. This indicates that the nickel silicide thin film with a preferential (121) orientation was prepared.

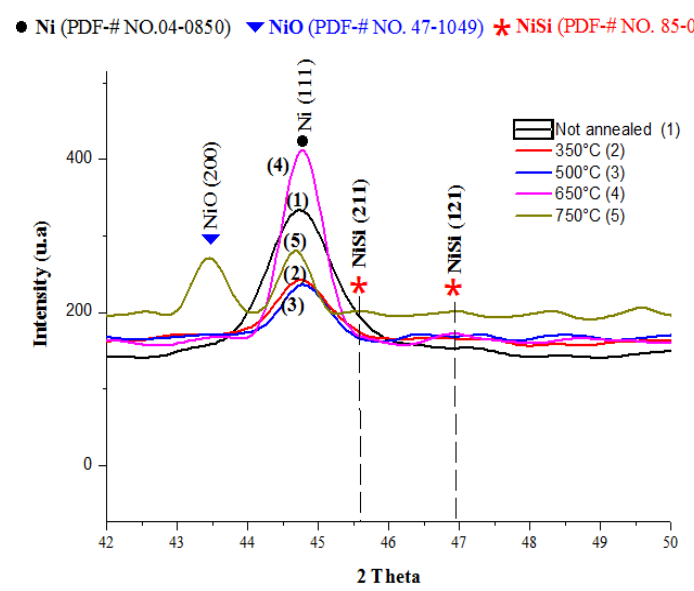

Fig. 4 - XRD spectra $\left(42^{\circ}<2 \theta<50^{\circ}\right)$ of the $\mathrm{Ni}(56 \mathrm{~nm}) / \mathrm{Si}$ film after annealing from $350{ }^{\circ} \mathrm{C}$ to $750{ }^{\circ} \mathrm{C}$ for $30 \mathrm{~min}$

\subsection{Resistivity Measurements}

The objective of the following experiment is to measure film $(\mathrm{Ni} / \mathrm{Si})$ resistances as a function of the annealing temperature. The sheet resistance $R s$ is measured by the four-point method. A four-point probe system consists of four contact needles separated by a distance $(s)$ aligned linearly or in a square configuration. Refer to Fig. 5 for detail.

A direct current is applied to probe 1 across the substrate or film and measured on probe 4 . As the current travels across the film, potential drops occur due to the internal resistance of the film. These potential differences are measured by probes 2 and 3. From the voltage and current measurements along with the film thickness $(w)$ and probe spacing $(s)$, the resistivity of the layer can easily be calculated.

Fig. 6 shows the variation of the sheet resistance as a function of temperature of RCA annealing for two substrates, namely $\mathrm{Ni}(35 \mathrm{~nm}) / \mathrm{Si}$ and $\mathrm{Ni}(56 \mathrm{~nm}) / \mathrm{Si}$. The annealing time is $30 \mathrm{~min}$.

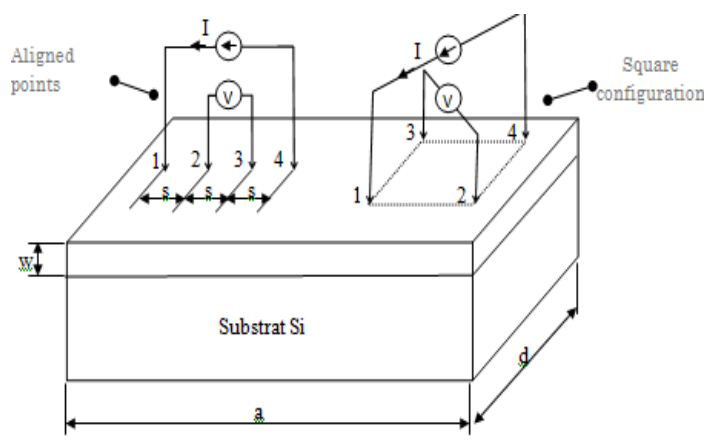

Fig. 5 - Experimental setup and arrangement of the measuring tips on the sample

In order to monitor the high-temperature stability of $\mathrm{Ni}(35 \mathrm{~nm}) / \mathrm{Si}(100)$ and $\mathrm{Ni}(56 \mathrm{~nm}) / \mathrm{Si}(100)$ systems, sheet resistance measurements were made after RCA annealing at different temperatures. The results are shown in Fig. 6.

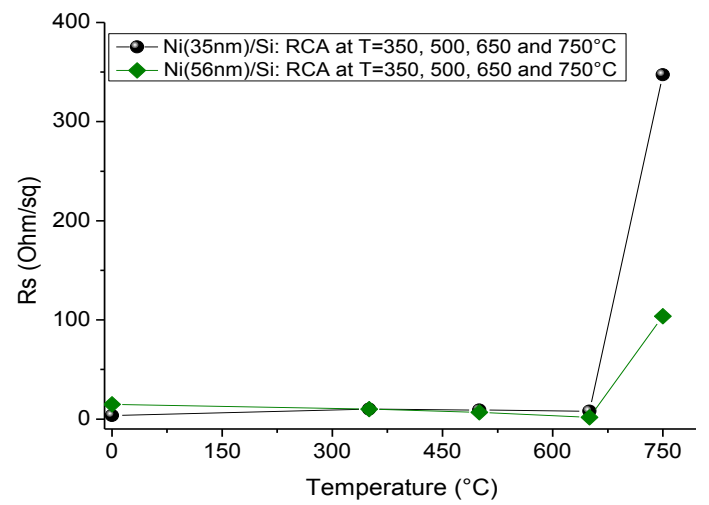

Fig. 6 - Evolution of $R s$ for different RCA annealing temperatures of the two substrates: $\mathrm{Ni}(35 \mathrm{~nm}) / \mathrm{Si}$ and $\mathrm{Ni}(56 \mathrm{~nm}) / \mathrm{Si}$

It can be seen that NiSi films are stable between 0 and $650{ }^{\circ} \mathrm{C}$. The sheet resistance of the film (NiSi) obtained is of the order of $7.6 \Omega / \mathrm{sq}$, a value is entirely acceptable for making electrical contact [14]. The ramp used has, in terms of $R s$, only little influence on the degradation of the film, the only point of difference is located at $750{ }^{\circ} \mathrm{C}$, where we see that the resistance goes to maximum values equal to $103 \Omega / \mathrm{sq}$ and $340 \Omega / \mathrm{sq}$ for $\mathrm{Ni}(35 \mathrm{~nm}) / \mathrm{Si}$ and $\mathrm{Ni}(56 \mathrm{~nm}) / \mathrm{Si}$ systems, respectively.

The high sheet resistance at high temperatures corresponds to nickel monoxides $\mathrm{NiO}(111)$ and $\mathrm{NiO}(220)$ formed for the $\mathrm{Ni}(56 \mathrm{~nm}) / \mathrm{Si}$ substrate and to nickel trioxide $\mathrm{Ni}_{2} \mathrm{O}_{3}(202)$ for the $\mathrm{Ni}(35 \mathrm{~nm}) / \mathrm{Si}$ substrate.

To better see the effect of the thickness of the nickel film on the sheet resistance, we preferred to represent the superimposed curves. We find that there is a significant difference at temperatures above $650{ }^{\circ} \mathrm{C}$. This also allowed us to conclude that the smaller the thickness of the film, the greater the value of the resistance $R s$, and this for temperatures above $650{ }^{\circ} \mathrm{C}$.

\subsection{Atomic Force Microscopy (AFM)}

In our study, AFM was used to determine the morphological properties of thin films for characterizing the RMS parameter. The quadratic mean of the roughness, called RMS (root mean square), is defined according to the relation [15]:

$$
R M S=\sqrt{\frac{\sum_{i=1}^{N}\left(Z_{i}-\bar{Z}\right)^{2}}{N}},
$$

where $Z_{i}, \bar{Z}$ and $N$ define respectively the local height, the average height of the characterized surface and the number of measured points.

AFM is typically used to investigate the surface topography of a sample. Unlike other microscopy, AFM gives the most accurate representation of the sample's surface with atomic level resolution. Such resolution is capable of resolving the grain sizes and shapes as well as the surface roughness of a sample.

By way of comparative example, we have measured the mean roughness of the reference sample (as-deposited), it has been evaluated at $11.2 \mathrm{~nm}$. The films deposited initially amorphous have a smooth surface (Fig. 7). After being annealed at $650{ }^{\circ} \mathrm{C}$, a remarkable increase was observed in roughness of the order of $90.41 \mathrm{~nm}$ which is attributed to the formation of new phases $\mathrm{Ni}$ - 
$\mathrm{Si}, \mathrm{NiO}$ and $\mathrm{Ni}_{2} \mathrm{O}_{3}$. Also, the maximum thickness increases from 130 to $400 \mathrm{~nm}$ which is about 3 times.
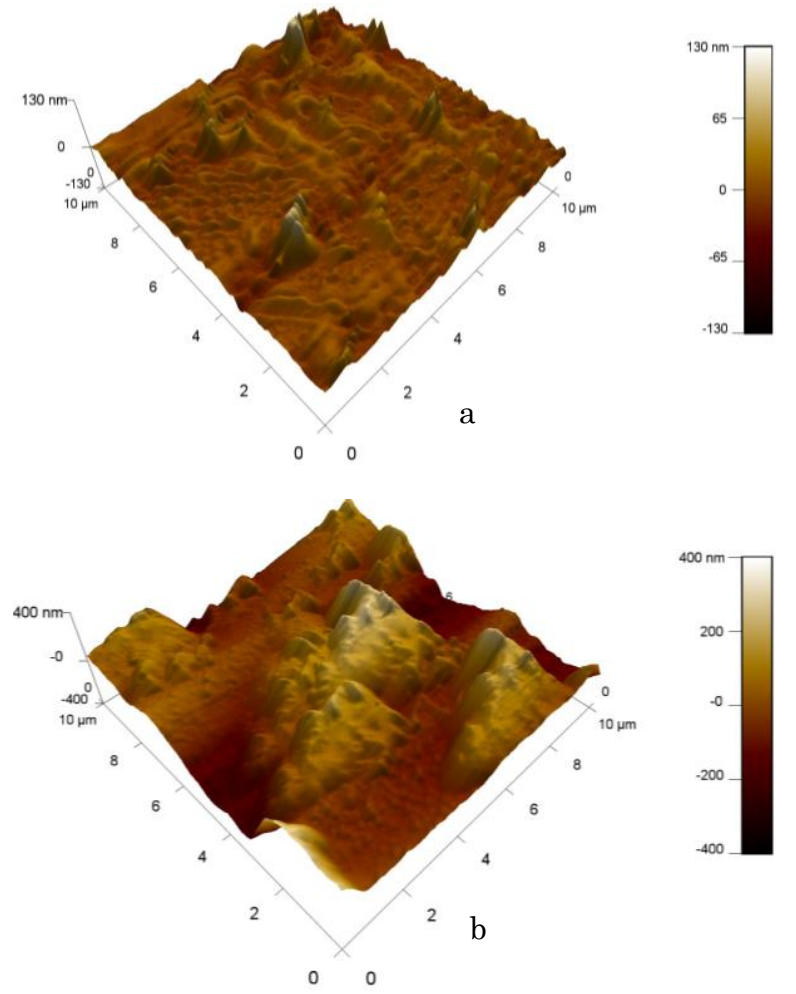

Fig. 7 - AFM images: (a) of $\mathrm{Ni}(35 \mathrm{~nm}) / \mathrm{Si}$ as-deposited, (b) of $\mathrm{Ni}(35 \mathrm{~nm}) / \mathrm{Si} \mathrm{RCA}$ annealed at $650{ }^{\circ} \mathrm{C}$ for $30 \mathrm{~min}$

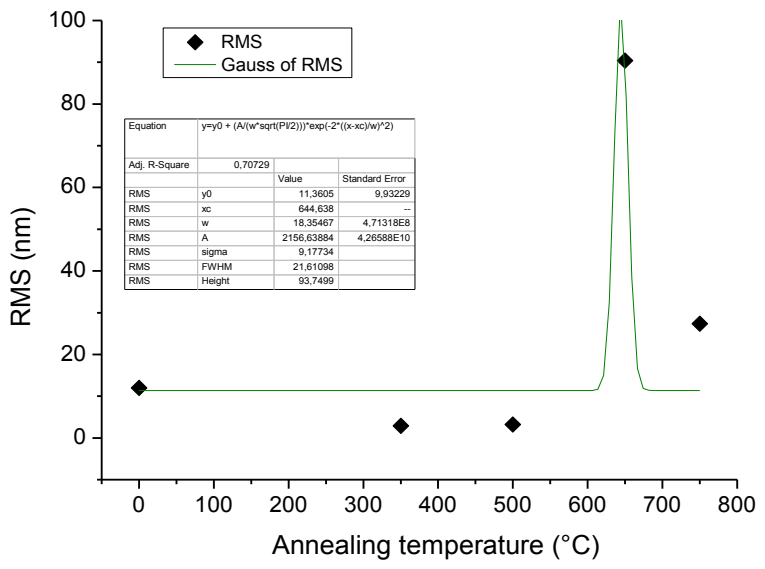

Fig. 8 - RMS roughness as a function of temperature for $30 \mathrm{~min}$ for the $\mathrm{Ni}(35 \mathrm{~nm}) / \mathrm{Si}(100)$ system

Fig. 8 illustrates the evolution of the average RMS surface roughness as a function of the RCA annealing temperature of the $\mathrm{Ni}(35 \mathrm{~nm}) / \mathrm{Si}$ substrate. In this figure, we observe stability of the roughness value with the annealing temperature between 0 and $500{ }^{\circ} \mathrm{C}$, and it goes through a maximum at $650{ }^{\circ} \mathrm{C}$, which can be attributed to a notable increase in the grain size.

The resulting morphology properties of the silicide layer are very promising which confirm the structural and electrical stability of NiSi.

\section{CONCLUSIONS}

Several works in the literature have focused on the development and characterization of thin films of metal oxides by different deposition techniques and heating modes. The variation of their properties has been studied according to several parameters and deposition conditions for various applications in the electronics and optics industry. In this context, the aim of this work was to study the influence of the RCA vacuum annealing temperature on the stability of the Ni/Si contact for the $\mathrm{Ni}(35 \mathrm{~nm}) / \mathrm{Si}$ and $\mathrm{Ni}(56 \mathrm{~nm}) / \mathrm{Si}$ systems.

From the results obtained, we can conclude the following.

- For the non-annealed sample, we do not observe any reaction between silicon and nickel in the two systems studied.

- For the $\mathrm{Ni}(56 \mathrm{~nm}) / \mathrm{Si}$ system: the only film present is that of the monoxide $\mathrm{NiO}$ which appears at the start of annealing at $350{ }^{\circ} \mathrm{C}$.

- For the $\mathrm{Ni}(35 \mathrm{~nm}) / \mathrm{Si}$ system: formation of the two oxide films, namely, nickel monoxide $\mathrm{NiO}$ which appears from annealing at $500{ }^{\circ} \mathrm{C}$ and nickel trioxide $\mathrm{Ni}_{2} \mathrm{O}_{3}$ at $650^{\circ} \mathrm{C}$. We notice that the $\mathrm{NiO}$ peak appears first.

- Formation of the monosilicide NiSi phase at $650{ }^{\circ} \mathrm{C}$.

- The absence of certain phases (stable referring to the phase diagram; e.g. $\mathrm{NiSi}_{2}, \mathrm{Ni}_{2} \mathrm{Si} \mathrm{Ni}_{3} \mathrm{Si}_{2}$ ) in the two systems studied. This can be explained by the use of another heating mode (rapid thermal annealing (RTA)).

It is also important to note good coherence between the XRD results with those of the sheet resistance and the RMS surface roughness. We deduce that there is stability of the resistance values $R s$ and RMS roughness between 0 and $650{ }^{\circ} \mathrm{C}$ caused by stability of the films formed.

Thickness of the deposited film inversely influences the values of the sheet resistance $R s$ at high temperatures. This therefore leads to the fact that the resistance of nickel trioxide $\mathrm{Ni}_{2} \mathrm{O}_{3}$ is greater than that of nickel monoxide $\mathrm{NiO}$.

In addition, it would be interesting to be able to complete this study with observations using transmission electron microscopy (TEM) in order to better understand the evolution of grain growth towards the surface of the substrate.

\section{REFERENCES}

1. P.S. Lee, D. Mangelinck, K.L. Pey, J. Ding, D.Z. Chi, J.Y. Dai, A. See, J. Electron. Mater. 30, 1554 (2001).

2. B. Froment, M. Muller, H. Brut, R. Pantel, V. Carron, H. Achard, A. Halimaoui, F. Boeuf, F. Wacquant, C. Regnier, D. Ceccarelli, R. Palla, A. Beverina, V. DeJonghe, P. Spinelli, O. Leborgne, K. Bard, S. Lis, V. Tirard, P. Morin, F. Trentesaux, V. Gravey, T. Mandrekar, D. Rabilloud, S. Van, E. Olson, J. Diedrick, CMOS, ESSDERC, 215 (2003).

3. C. Lavoie, F.M. d'Heurle, C. Detavernier, Jr. C. Cabral, Microelectron. Eng. 70, 144 (2003).

4. J.A. Kittl, K. Opsomer, C. Torregiani, C. Demeurisse, S. Mertens, D.P. Brunco, M.J.H. Van Dal, A. Lauwers, Mater. Sci. Eng. B 154, 144 (2008)

5. J. Chen, J.-P. Colinge, D. Flandre, R. Gillon, J.P. Raskin, D. Vanhoenacker, J. Electrochem. Soc. 144, 2437 (1997).

6. S.-L. Zhang, M. Ostling, Crit. Rev. Solid State Mater. Sci., 
28, 1 (2003).

7. D. Ma, D.Z. Chi, M.E. Loomans, W.D. Wang, A.S.W. Wong, S.J. Chua, Acta Mater. 54, 4905 (2006).

8. H. Iwai, T. Ohguro, S. Ohmi, Microelectron. Eng. 60, 157 (2002).

9. J.A Kittl, M.A. Pawlak, C. Torregiani, A. Lauwers, C. Demeurisse, C. Vrancken, P.P. Absil, S. Biesemans, Appl. Phys. Lett. 91, 232102 (2007).

10. N.A. Samoom, H.K. Atty, A.A.W. Ashoor, A.A. Hateef, International Journal of Physics, Chemistry and Mathematics (IJPCM). 1, 01 (2013).

11. H.L. Chen, Y.M. Lu, W.S. Hwang, Thin Solid Films 498, 266 (2006).
12. L. Herissi, Élaboration et caractérisation de couches minces d'oxydes métalliques destinées à des applications optoélectroniques, Thèse de doctorat en sciences, Université Oum El Bouaghi, Algérie (2016).

13. Nicolas Breil, Contribution to the study of advanced siliciding techniques for CMOS technologies, Doctoral thesis, University of Lille 1 (2009).

14. H. Iwai, T. Ohguro, S. Ohmi, Microelectron. Eng, 60, 157 (2002)

15. Bruno Imbert, Etude de la formation du siliciure de nickelplatine intégré dans la fabrication de transistors CMOS, thèse de doctorat, Université Grenoble (2009).

\title{
Вплив температури вакуумного відпалу на бінарну систему $\mathrm{Ni} / \mathrm{Si}(100)$
}

\author{
R. Mezouar ${ }^{1}$, A. Merabet ${ }^{2}$, A. Bahloul ${ }^{3}$ \\ ${ }^{1}$ Laboratoire Matériaux et Systèmes Electroniques, Université Mohamed El Bachir El Ibrahimi de Bordj Bou \\ Arreridj, Bordj Bou Arreridj 34000, Algérie \\ ${ }^{2}$ Institue d'Optique et Mécanique de Précision, Université Farhat Abbas Setif, 19000, Algérie \\ ${ }^{3}$ Département de Génie de l'Environnement, Université Mohamed El Bachir El Ibrahimi de Bordj \\ Bou Arreridj, Bordj Bou Arréridj 34000, Algérie
}

\begin{abstract}
Металеві силіцидні плівки широко застосовуються в мікроелектронній промисловості, де їх використовують як випрямлячі та омічні контакти. Більшість металів вступає в реакцію 3 кремнієм, утворюючи силіцид; осадження тонкого металевого шару отримують різними техніками. Поширеними методами є вакуумне випаровування з ниткою розжарювання або електронною гарматою, розпилення та хімічне осадження з парової фази. Вакуумне осадження тонкого шару металу на кремніеву підкладку е одним з найбільш широко використовуваних методів. Металеву силіщидну плівку вирощують на кремніевій підкладці, а потім відпалюють при різних теплових умовах. У роботі для підготовки силіцидної плівки ми використовували як методику вакуумне випаровування PVD (фізичне осадження з парової фази) за допомогою нікелевої (Ni) нитки розжарювання високої чистоти. На підкладку природно окисленого $\mathrm{Si}(100)$ після високочастотної підготовки поверхні наносяться два шари нікелю 3 товщинами 56 нм і 35 нм. Потім ці різні зразки $(\mathrm{Ni}(56$ нм)/ $\mathrm{Si}(100)$ та $\mathrm{Ni}(35 \mathrm{~nm}) / \mathrm{Si}(100))$ відпалюють у вакуумі при різних температурах, рівних $350,500,650$ та $750{ }^{\circ} \mathrm{C}$, протягом 30 хв. Характеристика отриманих шарів проводилася наступними методиками: рентгенівською дифракцією (XRD) для вивчення структури плівок (фазова ідентифікація), чотириточковим зондом для вимірювання питомого поверхневого опору фази/фаз та дослідження шорсткості поверхні проводили за допомогою атомно-силовоі мікроскопії (AFM). Ріст $\mathrm{Ni}$ на природно окислених підкладках $\mathrm{Si}(100)$ вивчався різними методами, які підтвердили, що температура вакуумного відпалу має дуже важливий ефект, оскільки моносиліцидна фаза $\mathrm{NiSi}$ виникає від $650^{\circ} \mathrm{C}$. Морфологічний аналіз поверхні розділу виявив наявність різних фаз $\mathrm{NiSi}, \mathrm{NiO}$ та $\mathrm{Ni}_{2} \mathrm{O}_{3}$, що підтверджуеться структурним аналізом. Крім того, спостерігалася добра узгодженість результатів XRD з результатами вимірювання питомого поверхневого опору та середньоквадратичної шорсткості поверхні.
\end{abstract}

Ключові слова: Силіщид, Випаровування за ефектом Джоуля, Питомий поверхневий опір, RCA, XRD, AFM, RMS. 